\title{
SH003 induces apoptosis of DU145 prostate cancer cells by inhibiting ERK-involved pathway
}

\author{
Yu-Jeong Choi ${ }^{1}$, Youn Kyung Choi ${ }^{2}$, Kang Min Lee ${ }^{3}$, Sung-Gook Cho ${ }^{4}$, Soo-Yeon Kang ${ }^{3}$ and Seong-Gyu Ko ${ }^{5^{*}}$ (D)
}

\begin{abstract}
Background: Herbal medicines have been used in cancer treatment, with many exhibiting favorable side effect and toxicity profiles compared with conventional chemotherapeutic agents. SH0O3 is a novel extract from Astragalus membranaceus, Angelica gigas, and Trichosanthes Kirilowii Maximowicz combined at a 1:1:1 ratio that impairs the growth of breast cancer cells. This study investigates anti-cancer effects of SHOO3 in prostate cancer cells.

Methods: SH003 extract in 30\% ethanol was used to treat the prostate cancer cell lines DU145, LNCaP, and PC-3. Cell viability was determined by MTT and BrdU incorporation assays. Next, apoptotic cell death was determined by Annexin $\checkmark$ and 7-AAD double staining methods. Western blotting was conducted to measure protein expression levels of components of cell death and signaling pathways. Intracellular reactive oxygen species (ROS) levels were measured using $\mathrm{H}_{2}$ DCF-DA. Plasmid-mediated ERK2 overexpression in DU145 cells was used to examine the effect of rescuing ERK2 function. Results were analyzed using the Student's $t$-test and $P$-values $<0.05$ were considered to indicate statistically-significant differences.
\end{abstract}

Results: Our data demonstrate that SH003 induced apoptosis in DU145 prostate cancer cells by inhibiting ERK signaling. SH003 induced apoptosis of prostate cancer cells in dose-dependent manner, which was independent of androgen dependency. SHOO3 also increased intracellular ROS levels but this is not associated with its pro-apoptotic effects. SH003 inhibited phosphorylation of Ras/Raf1/MEK/ERK/p90RSK in androgen-independent DU145 cells, but not androgen-dependent LNCaP and PC-3 cells. Moreover, ERK2 overexpression rescued SH003-induced apoptosis in DU145 cells.

Conclusions: SH003 induces apoptotic cell death of DU145 prostate cancer cells by inhibiting ERK2-mediated signaling.

Keywords: SH003, Herbal medicine, Apoptosis, ERK pathway, DU145 human prostate cancer cells, Anticancer effect

\section{Background}

Prostate cancer is the second-most common cancer occurring in men in the United States [1]. Furthermore, the American Cancer Society notes that although the mortality of prostate cancer patients is low, prostate cancer still accounts for a high rate of cancer occurrence [2]. Therefore, the development of new drugs should aid prostate cancer patients.

\footnotetext{
* Correspondence: epiko@khu.ac.kr

${ }^{5}$ Department of Preventive Medicine, College of Korean Medicine, Kyung Hee University, 1 Hoegi, Seoul 130-701, Korea

Full list of author information is available at the end of the article
}

Almost all prostate cancers develop from glandular cells, and are therefore classified as adenocarcinomas. Prostate cancer cells are also classified into androgendependent and-independent groups. While apoptosis of androgen-dependent cells is induced by androgen ablation, other mechanisms are required to induce apoptosis of androgen-independent cells [3, 4]. Furthermore, androgenindependent cells proliferate rapidly and their presence is associated with a poor prognosis $[5,6]$. Therefore, the development of novel therapeutic strategies to treat androgen-unresponsive prostate cancer cells is required.

Commonly used prostate cancer cell lines include DU145, PC-3, and LNCaP cells, which have been derived 
from metastatic prostate cancer lesions from brain, bone, and lymph node tissues, respectively [7]. Because these cell lines originate from different organs and their associated tumor microenvironments are disparate, each cell line has distinct characteristics [8]. DU145 cells are androgen-insensitive and express prostate-specific antigen. These characteristics are typical of difficult-to-treat prostate cancer lesions.

The mitogen-activated protein kinases (MAPKs) are a family of kinases that modulate cell proliferation, survival, differentiation, and development $[9,10]$. MAPK pathways transduce signals from extracellular stimuli such as growth factors and mitogens to the nucleus [11-13]. Aberrant signaling of the MAPK ERK is tightly associated with cancer progression [14, 15]. Moreover, overexpression of ERK predicts a poor prognosis in many cancers $[16,17]$. Thus, ERK-mediated signaling represents a molecular target for cancer treatment [18]. Furthermore, many natural products exert anti-cancer effects through inhibiting ERK-mediated signaling [7, 8, 19].

Many patients have a growing interest in phytomedicines. Conventional chemotherapeutic agents can have significant side effects, and interest in the use of natural herbal medicines in the prevention and/or treatment of many diseases including cancer has been increasing [20, 21]. SH003 is an extract from Astragalus membranaceus (Am), Angelica gigas (Ag), and Trichosanthes Kirilowii Maximowicz (Tk). The herbal components of $\mathrm{SH} 003$ exhibit anti-cancer effects [19, 22, 23], and suppress breast cancer growth [24]. In the present study, we investigated whether SH003 exerts anti-cancer effects on human prostate cancer cells. We report that $\mathrm{SHOO3}$ induces apoptotic cell death in DU145 prostate cancer cells through inhibiting ERKmediated signaling.

\section{Methods}

\section{Preparation of $\mathrm{SH} 003$}

SH003 was extracted from Am (333 g), Ag (333 g), and Tk (333 g) at a 1:1:1 ratio, according to the principles of traditional Korean medicine. Each component underwent sensory evaluation by Korean Pharmacopoeia standards. Am and Tk were from China, and Ag was of Korean origin. These extracts were concentrated under reduced pressure at $\leq 60{ }^{\circ} \mathrm{C}$ and were obtained from Hanpoong Pharm and Foods Company (Jeonju, Korea) $[10,24]$. Dry powders were dissolved in $30 \%$ ethanol and were prepared as final stock concentrations of $20 \mathrm{mg} / \mathrm{mL}$.

\section{Cell culture and viability assay}

DU145 human prostate cancer cells were cultured in RPMI-1640 medium containing 10\% fetal bovine serum and $1 \%$ antibiotic. Cells were maintained in a humidified atmosphere with $5 \% \mathrm{CO}_{2}$ at $37{ }^{\circ} \mathrm{C}$. Cell viability was measured using the MTT assay (Sigma-Aldrich, USA). Cells were seeded on 96-well plates and treated with various concentrations of herbal extract for $72 \mathrm{~h}$. After treatment, MTT working solution was added and cells were incubated at $37{ }^{\circ} \mathrm{C}$ for a further $2 \mathrm{~h}$. Next, dimethyl sulfoxide was added to each well to dissolve the formazan crystals. The absorbance of each well was measured at $570 \mathrm{~nm}$ using an ELISA reader (Molecular Devices, Palo Alto, CA).

\section{Apoptosis analysis by flow cytometry}

Apoptotic cell death was determined by flow cytometry following Annexin V/7-AAD double staining. Cells were seeded and treated with various concentrations of SH0O3 for $48 \mathrm{~h}$. After treatment, cells were harvested, resuspended in binding buffer, and stained with Annexin V and 7-AAD. Flow cytometry was conducted using a FACSCalibur instrument (BD Biosciences, San Jose, CA, USA). Data were analyzed using CellQuest Pro software (BD Biosciences).

\section{Cell proliferation assay}

Cell proliferation was measured by labeling cells with bromodeoxyuridine (BrdU) and propidium iodide (PI) prior to flow cytometry. BrdU-positive cells and PI staining were used to identify cells in $S$ phase and expression of total DNA $[25,26]$. Cells were treated with SH003 for $48 \mathrm{~h}$ and labeled with $10 \mu \mathrm{M}$ BrdU (Sigma-Aldrich) for $1 \mathrm{~h}$ before harvesting. Cells were then trypsinized and fixed in $70 \%$ ethanol on ice for $20 \mathrm{~min}$. Next, cells were incubated with $2 \mathrm{M} \mathrm{HCl} / 0.5 \%$ Tween-20/phosphatebuffered saline (PBS) for $30 \mathrm{~min}$ at room temperature. After washing with $1 \%$ bovine serum albumin (BSA) in PBS, cells were stained with anti-BrdU antibody (1:50; Santa Cruz, CA, USA) in buffer (0.5\% Tween-20/1\% $\mathrm{BSA}$ in PBS) for $30 \mathrm{~min}$ at room temperature. Cells were washed and then incubated for $30 \mathrm{~min}$ at room temperature with goat anti-mouse IgG-FITC (1:100; Santa Cruz). Washed cells were resuspended in PI for 30 min on ice. Cell proliferation was analyzed by FACSCalibur using CellQuest Pro software.

\section{Western blot analysis}

DU145 cells were lysed in radioimmunoprecipitation assay buffer $(150 \mathrm{mM} \mathrm{NaCl}, 1 \%$ Triton X-100, 1\% sodium deoxycholate, $0.1 \%$ sodium dodecyl sulfate, $50 \mathrm{mM}$ Tris- $\mathrm{HCl}$ [pH 7.5], $2 \mathrm{mM}$ ethylenediaminetetraacetic acid) and $15 \mu \mathrm{g}$ of protein was separated on $6-12 \%$ gels by sodium dodecyl sulfate-polyacrylamide gel electrophoresis Proteins were transferred to polyvinylidene difluoride membranes and then membranes were blocked in PBS with $0.1 \%$ Tween-20 containing $1 \%$ BSA and $1.5 \%$ skim milk for $1 \mathrm{~h}$. After washing, the membranes were probed with primary antibody at $4{ }^{\circ} \mathrm{C}$ overnight, and then incubated with horseradish peroxidase-conjugated 
secondary antibody for $1 \mathrm{~h}$ at room temperature. The blot was developed using the EZ-western detection kit (Daeillab Service, Co., Seoul, Korea). Anti-cleaved caspase-8, -cleaved caspase-3, -PARP, -JNK, -p38, -pERK1/2, -p-SRC (Tyr-416 and Tyr-527), -SRC, -pSTAT3, -STAT3, -p-PI3K, -PI3K, -p-AKT (Ser-473), -AKT, -Ras, -p-Raf1 (Ser-259 and Ser-338), -p-MEK1/2,
-p-p90RSK (Ser-380), and -RSK1/RSK2/RSK3 antibodies were purchased from Cell Signaling Technology (Danvers, MA, USA). Anti- $\beta$-Actin, -p-JNK, -p-p38, -ERK2, and -Raf1 antibodies were obtained from Santa Cruz Biotechnology (Santa Cruz). The band intensities of specific antibodies were normalized and analyzed by ImageJ (Broken Symmetry Software, version 1.4.3.67).
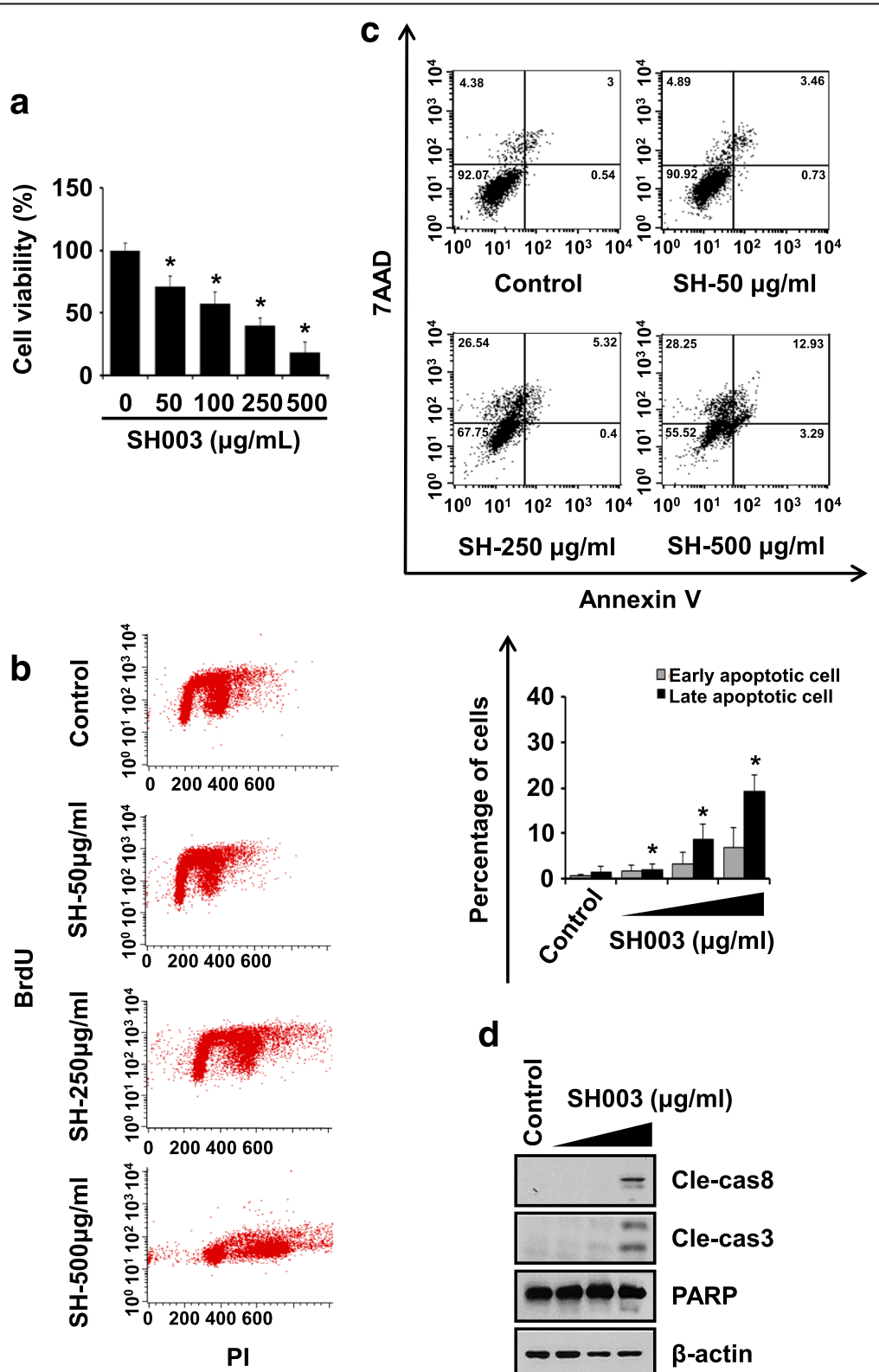

Fig. 1 SH003 induces apoptosis in DU145 cells. a DU145 cells were exposed to the indicated concentrations of SH003 for 72 h or treated with $30 \%$ ethanol as control, and cell viability was measured by the MTT assay. Experiments were performed three times independently and data are presented as the means \pm SD. $* P<0.05$. b Cells were treated with SH003 for $48 \mathrm{~h}$ and double-stained with anti-BrdU and propidium iodide (PI). Cell proliferation was determined using cells stained with BrdU for DNA synthesis and DNA content was detected by PI. The dot blots display BrdU incorporation (Y-axis) and DNA content (X-axis). c DU145 cells were exposed to SH003 for $48 \mathrm{~h}$ and then stained with Annexin V and 7-AAD before flow cytometry. Data are presented as the means \pm SD and experiments were replicated three times. ${ }^{*} P<0.05$. $\mathbf{d}$ Levels of apoptosis-related proteins were detected by western blotting with indicated antibodies after treatment with SH003 for $24 \mathrm{~h}$. $\beta$-actin was used as a loading control. Black triangle indicates increasing concentrations of SH003 $(50,250$, and $500 \mu \mathrm{g} / \mathrm{mL})$ 


\section{ROS measurement}

Intracellular levels of reactive oxygen species (ROS) were measured by flow cytometry. First, cells were seeded and treated with $\mathrm{SH} 003$ for $1 \mathrm{~h}$. In parallel with drug treatment for $1 \mathrm{~h}$, cells were stained using $2^{\prime}-7^{\prime}$-dichlorodihydrofluorescein diacetate $\left(\mathrm{H}_{2} \mathrm{DCF}-\mathrm{DA}\right)$ fluorescent dye to measure ROS production for $1 \mathrm{~h}$ at $37^{\circ} \mathrm{C}$. Cells were harvested, washed with PBS, filtered, and analyzed by FACSCalibur. N-acetyl-L-cysteine (NAC) was used as ROS scavenger.

\section{Transfections}

Cells were seeded and transfected with pEGEP-C1 or pEGEP-C1-ERK2 plasmids using Lipofectamine 2000
(Invitrogen, Carlsbad, CA, USA). Transfected cells were used for western blotting and apoptosis analyses.

\section{Statistical analysis}

Data are presented as the means \pm standard deviation (SD). Differences between groups were analyzed using a Student's $t$-test. $P$-values $<0.05$ were considered to indicate significant differences.

\section{Results}

SH003 induces apoptosis in DU145 prostate cancer cells We first investigated the effects of $\mathrm{SHOO3}$ on the viability of DU145 prostate cancer cells using MTT assays. Cells were exposed to $0,50,100,250$, or $500 \mu \mathrm{g} / \mathrm{mL}$ SH003

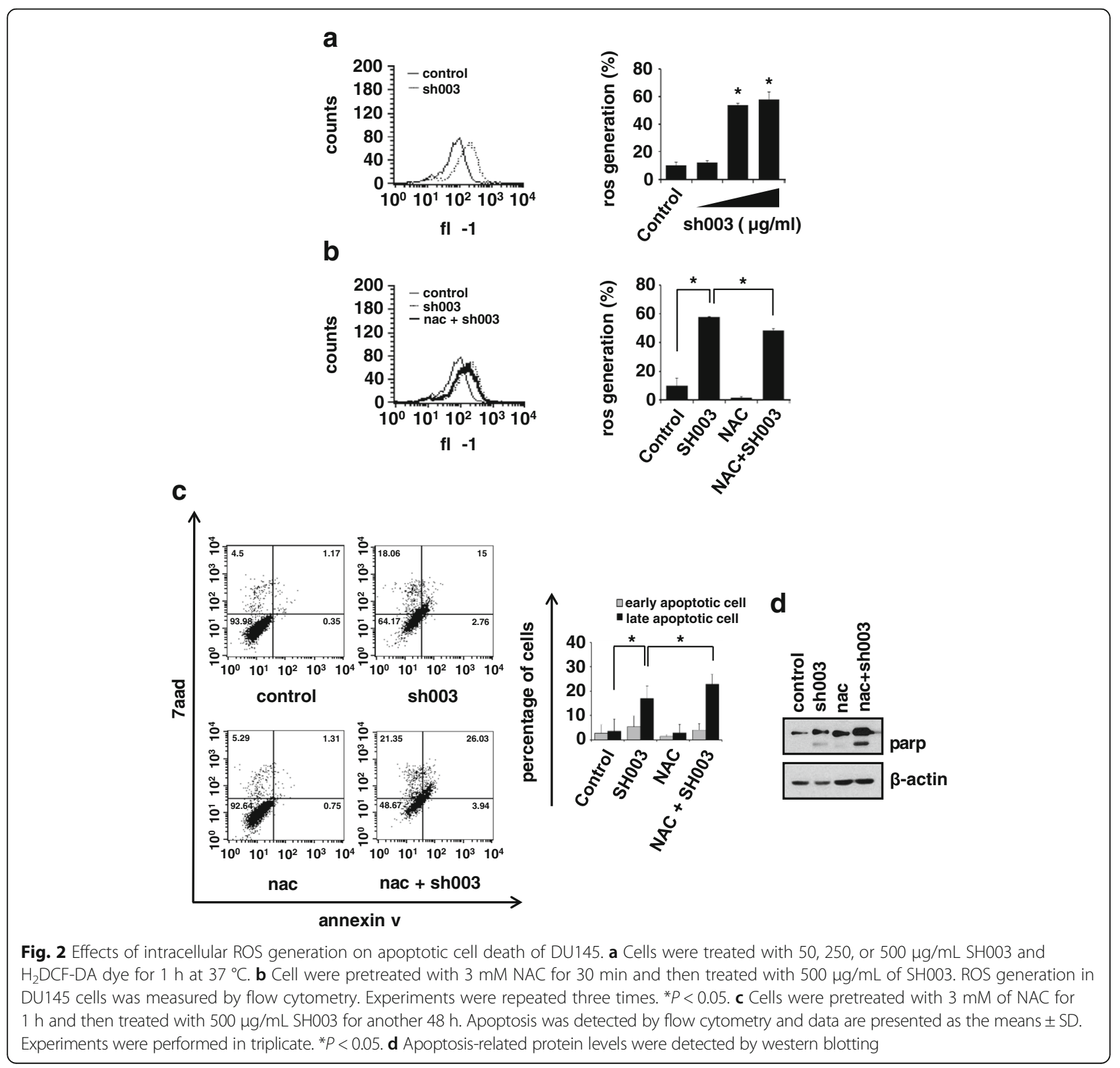


for $72 \mathrm{~h}$. SH003 decreased cell viability in a dosedependent manner (Fig. 1a). BrdU incorporation assays revealed that $\mathrm{SHOO3}$ reduced the percentage of BrdUpositive cells (Fig. 1b). These findings indicate that SH003 reduces DU145 cell viability.

We next treated DU145 cells with SH003 for $48 \mathrm{~h}$ and found that the number of apoptotic cells (Annexin $\mathrm{V}^{+} / 7-\mathrm{AAD}^{-}$and Annexin $\mathrm{V}^{+} / 7-\mathrm{AAD}^{+}$) increased in a dose-dependent manner (Fig. 1c). Consistently, SH003 induced cleavage of caspase-8, caspase-3, and PARP (Fig. 1d). These data indicate that SHOO3 induced apoptotic cell death in DU145 cells. Likewise, SH003 also induced apoptosis in both LNCaP and PC-3 cells (Additional file 1: Figure S1), suggesting that $\mathrm{SH} 003$ can induce apoptosis in multiple prostate cancer cell subtypes.

\section{Intracellular ROS generation is not involved in SH003-mediated apoptosis}

ROS induces apoptotic cell death [27-29], so we next examined whether treatment with $\mathrm{SH} 003$ increased intracellular ROS levels. SH003 induced ROS production in a dose-dependent manner (Fig. 2a). Moreover, SH003-

\section{a}

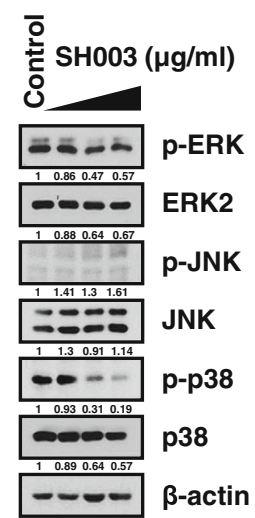

d

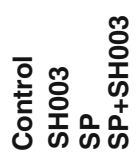

b

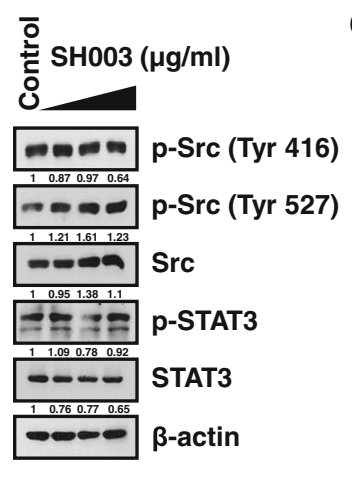

C

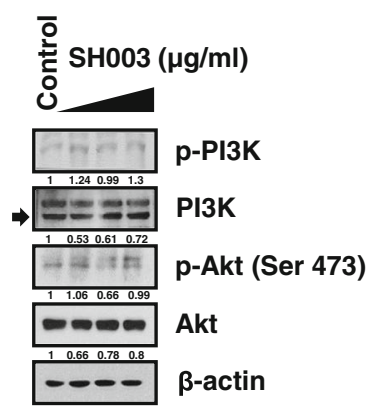

e

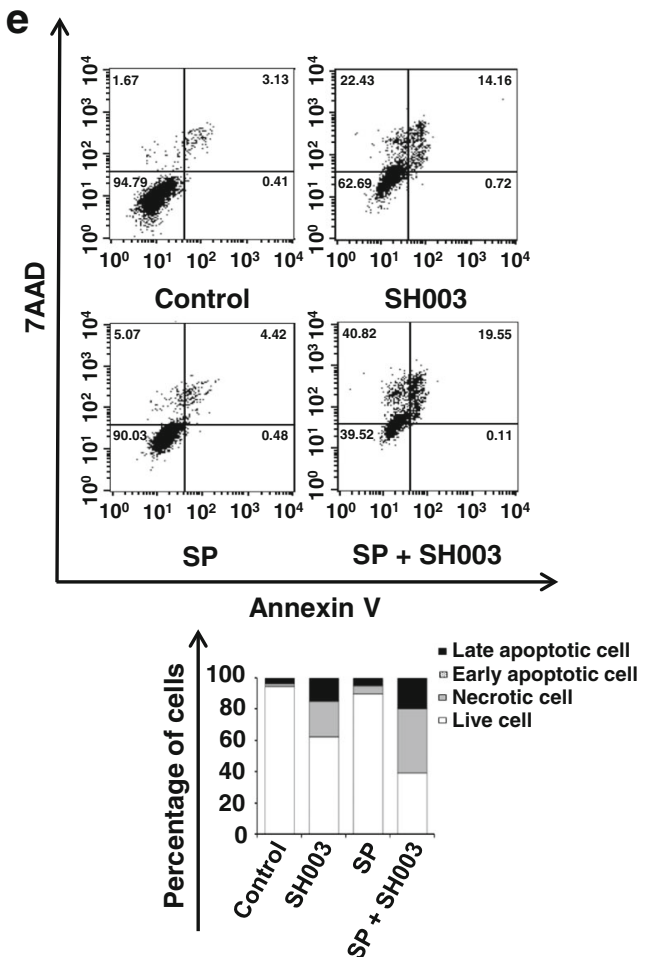

Fig. 3 Effects of SHOO3 on the activation of intracellular signaling pathways and induction of apoptosis by JNK phosphorylation in DU145 cells. DU145 cells were exposed to 50, 250, or $500 \mu \mathrm{g} / \mathrm{mL}$ SH003 for 15 min and western blotting was used to determine expression levels of a ERK, JNK, and p38 related MAPK components, b SRC-STAT3 signaling pathway components, or c PI3K-AKT pathway proteins. $\beta$-actin served as the internal control. d Cells were pretreated with $10 \mu \mathrm{M} \mathrm{SP600125} \mathrm{for} 30 \mathrm{~min}$ and then treated with $500 \mu \mathrm{g} / \mathrm{mL}$ SH003 for $24 \mathrm{~h}$. Levels of apoptosis-related proteins and p-JNK were measured by western blotting. e Cells were pretreated with $10 \mu \mathrm{M}$ of SP600125 for 30 min and then treated with $500 \mu \mathrm{g} / \mathrm{mL}$ SH003 for $48 \mathrm{~h}$ before staining with Annexin $\mathrm{V}$ and 7-AAD at room temperature in the dark. Levels of apoptosis were analyzed by flow cytometry. ${ }^{*} P<0.05$ 
induced increased intracellular ROS levels decreased when cells were treated with NAC (Fig. 2b). However, combination treatment with SH003 and NAC increased apoptosis (Fig. 2c and d), indicating that SH003mediated apoptosis did not require intracellular ROS generation.
SH003-induced JNK phosphorylation is not required for apoptotic cell death

We next examined the intracellular signaling pathways induced by SH003. SH0O3 reduced phosphorylation of both ERK and p38MAPK, but induced JNK phosphorylation (Fig. 3a). However, SH003 did not affect phosphorylation of

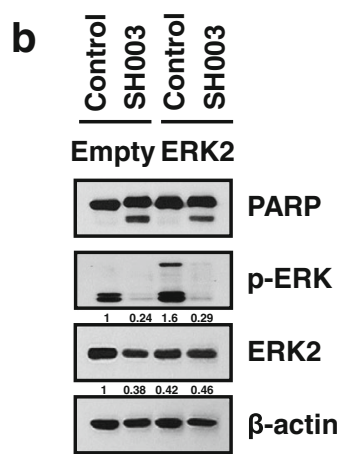

p-p90RSK (Ser 380)

RSK1/RSK2/RSK3

$\beta$-actin

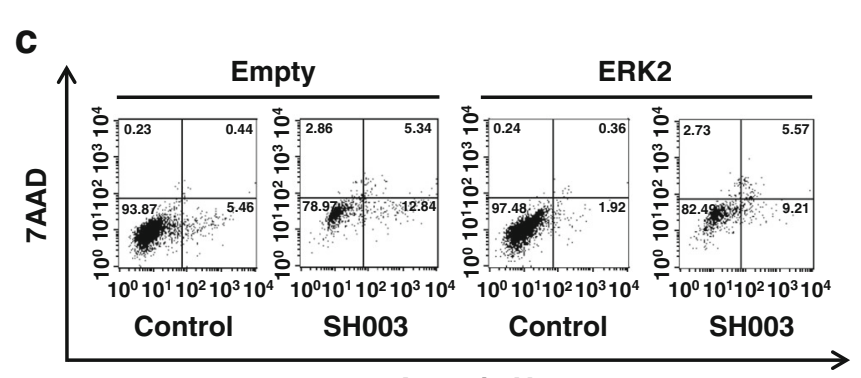

Annexin V
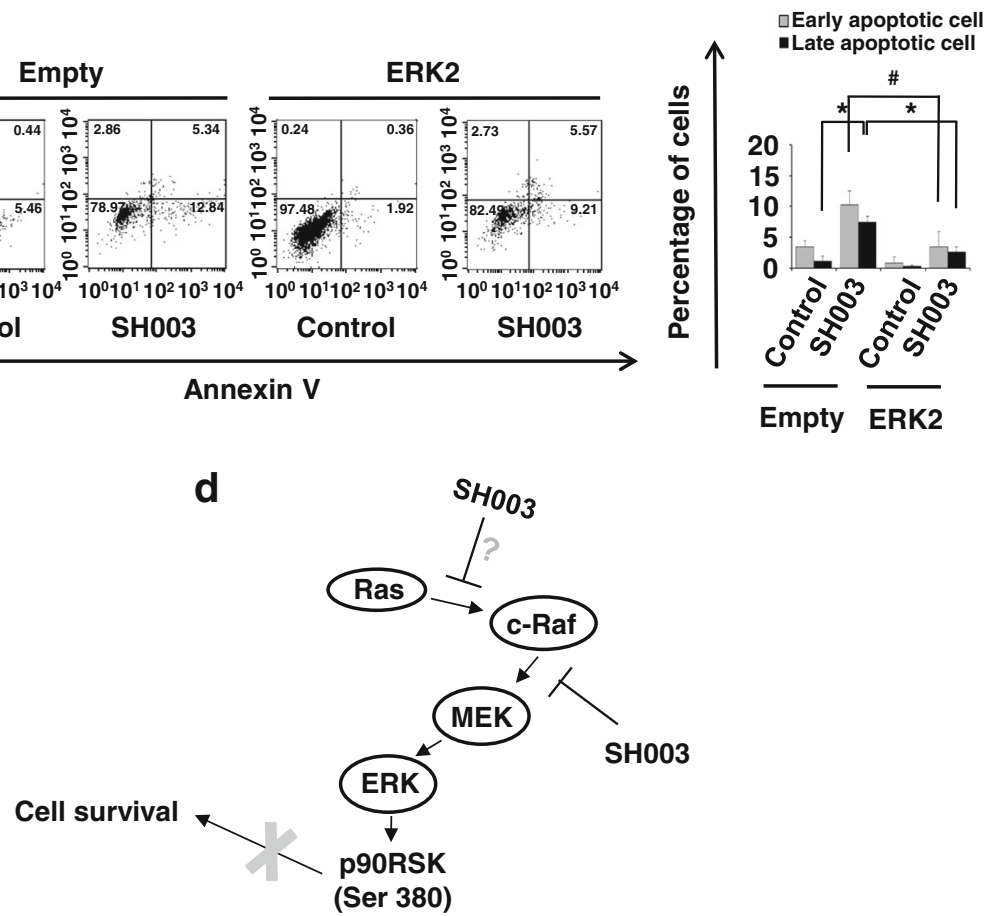

Fig. 4 SH003 induces apoptotic cell death in DU145 cells via the ERK signaling pathway. a Western blotting of ERK signaling-related protein expression levels in DU145 cells treated with indicated concentrations of SH003. b Western blotting of ERK2 and PARP levels in DU145 cells transfected with ERK2-expressing or control vectors and treated with indicated concentration of SH003 for 24 h. c Flow cytometry analysis of apoptotic cell death of DU145 cells transfected with the ERK2-expressing or control vectors. Results are presented as the means \pm SD of three independent experiments. ${ }^{*} P<0.05$ comparison of control vector-transfected cells with ERK2-transfected cells treated with SH003 in late apoptosis, $\# P<0.05$ comparison of ERK2-transfected cell with SH003 treatment in early apoptotic cells. $\mathbf{d}$ Schematic of the hypothetical system regulated by SH003. SHOO3 induces apoptosis in prostate cancer cells and inactivates ERK signaling 
SRC, STAT3, PI3K, or AKT (Fig. 3b and c). While our previous work found that $\mathrm{SHOO3}$ inhibits STAT3 in MDA-MB-231 breast cancer cells [24], this did not occur in DU145 prostate cancer cells. Therefore, SH003 may inhibit the growth of different cancer cells using cell-specific mechanisms.

Because SH003 activated JNK phosphorylation in DU145 cells, we next investigated whether SH003-mediated apoptosis is regulated by JNK signaling. When DU145 cells were treated with the JNK1/2 inhibitor SP600125 prior to SH003 treatment, apoptotic cell death was increased (Fig. 3d and e). These results indicate that SH003-induced JNK phosphorylation is not associated with SH003mediated induction of apoptosis in DU145 cells.

\section{SH003 inhibits ERK phosphorylation to promote apoptotic cell death}

We next examined whether SH003 regulates the ERK signaling pathway. SH003 reduced phosphorylation of Raf1, MEK, ERK, and p90RSK and decreased Ras levels (Fig. 4a). Furthermore, exogenous expression of ERK in DU145 cells decreased SH003-induced PARP cleavage (Fig. 4b). Accordingly, ERK overexpression reduced SH003-mediated apoptosis based on Annexin V/7-AAD staining (Fig. 4c). These data indicate that $\mathrm{SHOO3} \mathrm{in-}$ duced apoptotic cell death of DU145 cells by inhibiting ERK-associated signaling (Fig. 4d). However, SH003 did not alter the ERK phosphorylation status in LNCaP and PC-3 cells (Additional file 2: Figure S2). This suggests that $\mathrm{SHOO3}$ induced apoptosis by intracellular mechanisms other than ERK signaling in these cells.

\section{Discussion}

SH003 is a modified traditional herbal medicine that we have recently developed and used to inhibit breast cancer growth and metastasis [24, 30-32]. Our present findings demonstrate that $\mathrm{SHOO3}$ can also cause the apoptotic cell death of prostate cancer cells. We found that SH003 induced apoptosis in DU145, LNCaP, and $\mathrm{PC}-3$ prostate cancer cells. These findings suggest that the pro-apoptotic effects of $\mathrm{SHOO3}$ are not restricted to specific prostate cancer cell types. Taken together with our recent studies describing SH003-mediated breast cancer cell death $[24,30,33]$, these results suggest that the anti-cancer effect of SHOO3 may also not be limited to cancer types.

SH003 increased intracellular ROS levels in DU145 cells. However, while excessive ROS levels can induce apoptosis [28, 34], our data reveal that SH0O3 induces apoptosis of DU145 cells independently of ROS levels. Although we still do not know the role of SH003-mediated increased ROS levels in DU145 cells, it is possible that the levels of ROS present may be insufficient to directly induce apoptosis. Additionally, SH003-mediated
JNK phosphorylation was also not associated with SH003-mediated apoptosis of DU145 cells. Therefore, the precise role of SH003-induced JNK activation remains to be determined.

Our data show that SH003-mediated inhibition of ERK phosphorylation is crucial for apoptotic cell death, with these findings confirmed by rescue experiments. We have also recently shown that SH003 inhibits VEGFR phosphorylation in VEGF-stimulated endothelial cells [32]. Moreover, SH003 also reduces EGFR phosphorylation in MDA-MB-231 breast cancer cells. Presently, we found that SH0O3 inhibits Raf phosphorylation. Inhibition of EGFR signaling is an effective strategy for prostate cancer treatment [35-37]. While additional findings and supportive data are required to better understand the mechanisms by which SH003 functions, it is possible that SH003 directly regulates receptor tyrosine kinase-mediated signaling in cancer. Our future studies will focus on this issue. Our present findings indicate that SH003-induced ERK inhibition-mediated apoptosis is limited to DU145 cells. These data suggest that SH003 may evoke different intracellular signaling mechanisms to effect its anti-cancer functions.

\section{Conclusions}

SH003 causes apoptosis of DU145 prostate cancer cells by inhibiting ERK signaling. While a more complete understanding of how SH003 differentially affects different subsets of prostate cancer cell populations is still required, this study suggests that $\mathrm{SHOO3}$ could be beneficial for treating prostate cancer.

\section{Additional files}

Additional file 1: Figure S1. Effects of $\mathrm{SH} 003$ on apoptosis in LNCaP and PC-3 cells. a LNCaP and PC-3 cells were treated to the indicated concentrations with $\mathrm{SH} 003$ for $72 \mathrm{~h}$ and with $30 \%$ ethanol as control. Cell viability was measured by the MTT assay. Data represents the mean SD. ${ }^{*} P,<0.05$. b Cells were exposed to SH003 for $48 \mathrm{~h}$. The harvested-cells were double-stained with Annexin $\mathrm{V}$ and $7-A A D$ for 15 min at RT in the dark. The apoptotic cells were analyzed by FACSCalibur. Data represents the mean \pm SD. c After treatment with SH003 for $24 \mathrm{~h}$, the apoptosis-related protein levels were confirmed by western blot. $\beta$-actin was used as a loading control. Black triangle means concentrations of $\mathrm{SHOO3}(50,250$, $500 \mu \mathrm{g} / \mathrm{ml}$ ). (PDF $118 \mathrm{~kb}$ )

Additional file 2: Figure S2. Regulation of protein expression of $\mathrm{SH} 003$ on ERK signaling pathway in LNCaP and PC-3 cells. Cells were treated with $\mathrm{SHOO3}$ for $15 \mathrm{~min}$ and then detected ERK-related protein expression levels by western blots. Protein expression levels shown above were quantified using ImageJ. (PDF $111 \mathrm{~kb}$ )

\section{Abbreviations}

7-AAD: 7-Aminoactinomycin D; Ag: Angelica gigas; Am: Astragalus membranaceus; $\mathrm{H}_{2}$ DCF-DA: 2'-7'-dichlorodihydrofluorescein diacetate; MAPK: Mitogen-activated protein kinase; MTT: 3-(4,5-dimethylthiazol-2-yl)-2,5-diphenyltetrazolium bromide; ROS: Reactive oxygen species; SD: Standard deviation; Tk: Trichosanthes Kirilowii Maximowicz 


\section{Acknowledgments}

This research was supported by a grant from Korean Medicine R\&D Project of the Ministry of Health and Welfare (B110043), and by the National Research Foundation of Korea (NRF) grant funded by the Korea government (MSIP) (2007-0054931).

Contract/grant sponsor: Ministry of Health and Welfare; contract/grant number: B110043.

Contract/grant sponsor: National Research Foundation of Korea (NRF): contract/grant number: 2007-0054931.

\section{Availability of data and materials}

All data and materials are described within the article.

\section{Authors' contributions}

CYJ performed experiments, analyzed data, and drafted the article. CYK interpreted data, drafted the article, and designed the study. LKM performed experiments. CSG drafted the article and conceived of the study. KSY performed experiments. KSG organized and designed the study. All authors read and approved the final manuscript.

\section{Competing interests}

The authors declare that they have no competing interests.

\section{Consent for publication}

This section is not applicable in this research.

\section{Ethics approval and consent to participate}

This section is not applicable in this research.

\section{Author details}

'Department of Cancer Preventive Material Development, Graduate School, Kyung Hee University, Seoul 02447, Korea. ${ }^{2}$ Jeju International Marine Science center for Research \& Education, Korea Institute of Ocean Science \& Technology (KIOST), Jeju 63349, Korea. ${ }^{3}$ Department of Science in Korean Medicine, Graduate School, Kyung Hee University, Seoul 02447, Korea. ${ }^{4}$ Department of Biotechnology, Korea National University of Transportation, Jeungpyeong, Chungbuk 368-701, Korea. ${ }^{5}$ Department of Preventive Medicine, College of Korean Medicine, Kyung Hee University, 1 Hoegi, Seoul 130-701, Korea.

\section{Received: 27 July 2016 Accepted: 17 November 2016}

\section{Published online: 07 December 2016}

\section{References}

1. Garcia V, Lara-Chica M, Cantarero I, Sterner O, Calzado MA, Munoz E. Galiellalactone induces cell cycle arrest and apoptosis through the ATM/ATR pathway in prostate cancer cells. Oncotarget. 2016;7(4):4490-506.

2. Siegel R, Naishadham D, Jemal A. Cancer statistics, 2013. Ca-Cancer J Clin. 2013;63(1):11-30.

3. Denmeade SR, Lin XS, Isaacs JT. Role of programmed (apoptotic) cell death during the progression and therapy for prostate cancer. Prostate. 1996;28(4):251-65.

4. Richter E, Srivastava S, Dobi A. Androgen receptor and prostate cancer. Prostate Cancer Prostatic Dis. 2007;10(2):114-8.

5. Adhami VM, Aziz MH, Reagan-Shaw SR, Nihal M, Mukhtar H, Ahmad N Sanguinarine causes cell cycle blockade and apoptosis of human prostate carcinoma cells via modulation of cyclin kinase inhibitor-cyclin-cyclindependent kinase machinery. Mol Cancer Ther. 2004;3(8):933-40.

6. Tang DG, Porter AT. Target to apoptosis: a hopeful weapon for prostate cancer. Prostate. 1997;32(4):284-93.

7. Liu AY. Differential expression of cell surface molecules in prostate cancer cells. Cancer Res. 2000;60(13):3429-34

8. Fu YM, Yu ZX, Lin H, Fu X, Meadows GG. Selective amino acid restriction differentially affects the motility and directionality of DU145 and PC3 prostate cancer cells. J Cell Physiol. 2008;217(1):184-93.

9. Chang L, Karin M. Mammalian MAP kinase signalling cascades. Nature. 2001;410(6824):37-40.

10. Yoon S, Seger R. The extracellular signal-regulated kinase: multiple substrates regulate diverse cellular functions. Growth Factors. 2006;24(1):21-44.

11. Wada T, Penninger JM. Mitogen-activated protein kinases in apoptosis regulation. Oncogene. 2004;23(16):2838-49.
12. Chang F, Steelman LS, Lee JT, Shelton JG, Navolanic PM, Blalock WL, Franklin RA, McCubrey JA. Signal transduction mediated by the Ras/Raf/ MEKJERK pathway from cytokine receptors to transcription factors: potential targeting for therapeutic intervention. Leukemia. 2003;17(7):1263-93.

13. Cantley LC, Auger KR, Carpenter C, Duckworth B, Graziani A, Kapeller R, Soltoff S. Oncogenes and signal transduction. Cell. 1991;64(2):281-302.

14. Xia Z, Dickens M, Raingeaud J, Davis RJ, Greenberg ME. Opposing effects of ERK and JNK-p38 MAP kinases on apoptosis. Science. 1995;270(5240):1326-31.

15. Chong $H$, Vikis HG, Guan KL. Mechanisms of regulating the Raf kinase family. Cell Signal. 2003;15(5):463-9.

16. McCubrey JA, Steelman LS, Chappell WH, Abrams SL, Wong EW, Chang F, Lehmann B, Terrian DM, Milella M, Tafuri A, et al. Roles of the Raf/MEK/ERK pathway in cell growth, malignant transformation and drug resistance. Biochim Biophys Acta. 2007:1773(8):1263-84.

17. Roberts PJ, Der CJ. Targeting the Raf-MEK-ERK mitogen-activated protein kinase cascade for the treatment of cancer. Oncogene. 2007:26(22):3291-310.

18. Herrero A, Pinto A, Colon-Bolea P, Casar B, Jones M, Agudo-lbanez L, Vidal R, Tenbaum SP, Nuciforo P, Valdizan EM, et al. Small molecule inhibition of ERK dimerization prevents tumorigenesis by RAS-ERK pathway oncogenes. Cancer Cell. 2015:28(2):170-82.

19. Cho WC, Leung KN. In vitro and in vivo anti-tumor effects of Astragalus membranaceus. Cancer Lett. 2007;252(1):43-54.

20. Sparreboom A, Cox MC, Acharya MR, Figg WD. Herbal remedies in the United States: potential adverse interactions with anticancer agents. J Clin Oncol. 2004;22(12):2489-503.

21. Li X, Yang G, Li X, Zhang Y, Yang J, Chang J, Sun $X$, Zhou X, Guo Y, Xu Y, et al. Traditional Chinese medicine in cancer care: a review of controlled clinical studies published in chinese. PLoS One. 2013;8(4):e60338.

22. Son SH, Park KK, Park SK, Kim YC, Kim YS, Lee SK, Chung WY. Decursin and decursinol from Angelica gigas inhibit the lung metastasis of murine colon carcinoma. Phytother Res. 2011;25(7):959-64.

23. Fang EF, Zhang $\mathrm{CZ}$, Zhang L, Wong JH, Chan YS, Pan WL, Dan XL, Yin CM, Cho $\mathrm{CH}, \mathrm{Ng}$ TB. Trichosanthin inhibits breast cancer cell proliferation in both cell lines and nude mice by promotion of apoptosis. PLoS One. 2012;7(9):e41592.

24. Choi YK, Cho SG, Woo SM, Yun YJ, Park S, Shin YC, Ko SG. Herbal extract SH003 suppresses tumor growth and metastasis of MDA-MB-231 breast cancer cells by inhibiting STAT3-IL-6 signaling. Mediat Inflamm. 2014;2014:492173.

25. Haddad AQ, Venkateswaran V, Viswanathan L, Teahan SJ, Fleshner NE, Klotz LH. Novel antiproliferative flavonoids induce cell cycle arrest in human prostate cancer cell lines. Prostate Cancer Prostatic Dis. 2006;9(1):68-76.

26. Seiler JA, Conti C, Syed A, Aladjem MI, Pommier Y. The intra-S-phase checkpoint affects both DNA replication initiation and elongation: single-cell and -DNA fiber analyses. Mol Cell Biol. 2007;27(16):5806-18.

27. Circu ML, Aw TY. Reactive oxygen species, cellular redox systems, and apoptosis. Free Radic Biol Med. 2010;48(6):749-62.

28. Laurent A, Nicco C, Chereau C, Goulvestre C, Alexandre J, Alves A, Levy E, Goldwasser F, Panis Y, Soubrane O, et al. Controlling tumor growth by modulating endogenous production of reactive oxygen species. Cancer Res. 2005;65(3):948-56

29. Sullivan LB, Chandel NS. Mitochondrial reactive oxygen species and cancer. Cancer Metab. 2014;2:17

30. Choi YK, Cho SG, Choi YJ, Yun YJ, Lee KM, Lee K, Yoo HH, Shin YC, Ko SG. SH003 suppresses breast cancer growth by accumulating p62 in autolysosomes. Oncotarget. 2016.

31. Choi EK, Kim SM, Hong SW, Moon JH, Shin JS, Kim JH, Hwang IY, Jung SA, Lee DH, Lee EY, et al. SH003 selectively induces p73dependent apoptosis in triplenegative breast cancer cells. Mol Med Rep. 2016;14(4):3955-60.

32. Choi HS, Kim MK, Lee K, Lee KM, Choi YK, Shin YC, Cho SG, Ko SG. SH003 represses tumor angiogenesis by blocking VEGF binding to VEGFR2. Oncotarget. 2016;7(22):32969-79.

33. Woo SM, Kim AJ, Choi YK, Shin YC, Cho SG, Ko SG. Synergistic effect of SHOO3 and doxorubicin in triple-negative breast cancer. Phytother Res. 2016:30:1817-23.

34. Sainz RM, Lombo F, Mayo JC. Radical decisions in cancer: redox control of cell growth and death. Cancers. 2012;4(2):442-74.

35. Festuccia C, Gravina GL, Biordi L, D'Ascenzo S, Dolo V, Ficorella C, Ricevuto E, Tombolini V. Effects of EGFR tyrosine kinase inhibitor erlotinib in prostate cancer cells in vitro. Prostate. 2009;69(14):1529-37.

36. Di Lorenzo G, Tortora G, D'Armiento FP, De Rosa G, Staibano S, Autorino R, D'Armiento M, De Laurentiis M, De Placido S, Catalano G, et al. Expression 
of epidermal growth factor receptor correlates with disease relapse and progression to androgen-independence in human prostate cancer. Clin Cancer Res. 2002;8(11):3438-44.

37. Carrion-Salip D, Panosa C, Menendez JA, Puig T, Oliveras G, Pandiella A, De Llorens R, Massaguer A. Androgen-independent prostate cancer cells circumvent EGFR inhibition by overexpression of alternative HER receptors and ligands. Int J Oncol. 2012;41(3):1128-38.

Submit your next manuscript to BioMed Central and we will help you at every step:

- We accept pre-submission inquiries

- Our selector tool helps you to find the most relevant journal

- We provide round the clock customer support

- Convenient online submission

- Thorough peer review

- Inclusion in PubMed and all major indexing services

- Maximum visibility for your research

Submit your manuscript at www.biomedcentral.com/submit
Biomed Central 